\title{
Photocatalytic Ring Opening of $\alpha$-Epoxyketones in Cyclopentanone
}

\author{
Hamaid R. Memarian, Gholrokh Shokuhimehr, and Mousa Soleymani \\ Catalysis Division, Department of Chemistry, Faculty of Science, University of Isfahan, \\ 81746-73441 Isfahan, Iran \\ Reprint requests to Prof. Hamid R. Memarian. Fax: +98-311-6689732. \\ E-mail: memarian@sci.ui.ac.ir
}

Z. Naturforsch. 2011, 66b, 603-610; received January 4, 2011

\begin{abstract}
Electron transfer-induced ring opening of $\alpha$-epoxyketones by 2,4,6-triphenylpyrylium tetrafluoroborate (TPT) in cyclopentanone resulted in the diastereoselective formation of 2,5-dioxaspiro[4,4]nonanes through $\mathrm{C}_{\alpha}-\mathrm{O}$ bond cleavage and following nucleophilic attack of cyclopentanone to radical cation intermediates. The readiness for ring opening is influenced by the nature and the location of the additional substituent on the $\alpha$-epoxyketones.
\end{abstract}

Key words: Dioxolanes, Electron Transfer, $\alpha$-Epoxyketones, Photocatalyst, Ring Opening, Spiro Compounds

\section{Introduction}

Single electron transfer- (SET) induced ring opening of epoxides and $\alpha$-epoxyketones occurs in the presence of suitable electron-withdrawing catalysts or photocatalysts [1 -3]. In this case, the electron transfer process leads to the formation of radical cation intermediates, which upon attack of suitable nucleophiles accomplish the reaction. The ring opening reaction of $\alpha$-epoxyketones has been recognized as an important process not only in thermal but also in photochemical reactions, which occur either through a $\mathrm{C}-\mathrm{C}, \mathrm{C}_{\alpha}-\mathrm{O}$ or $\mathrm{C}_{\beta}-\mathrm{O}$ bond cleavage. Some of these reactions were reported using various catalysts or photocatalysts such as $\mathrm{AlCl}_{3}$ [4], p-toluenesulfonic acid [5], dicyanoanthracene (DCA) [2], tetracyanoethylene (TCNE) [1], 2,4,6-triphenylpyrylium tetrafluoroborate (TPT) [3, 610], 1-benzyl-2,4,6-triphenylpyridinium tetrafluoroborate (NBTPT) [11, 12], 2,3-dichloro-5,6-dicyano- $p$ benzoquinone (DDQ) $[13,14]$, and 7,7,8,8-tetracyano$p$-quinodimethane (TCNQ) [15].

2,4,6-triphenylpyrylium tetrafluoroborate (TPT) is widely used as an electron transfer photosensitizer for various organic transformations such as decarboxylation of amino acids [16], photooxidation of $N, N$-dibenzylhydroxylamine [17], photochemically promoted Diels-Alder reactions of 1,4-diaryl-1-azabutadienes with 2,3-dihydrofuran [18], [3+2]-cycloaddition of electron-rich olefins to oxiranecarbonitrile [19], and the above mentioned reactions.
In our recent studies, we have investigated the photocatalytic ring opening of various $\alpha$-epoxyketones of interest by TPT as photocatalyst in the presence of methanol [7], cyclohexanone [8], acetic acid [9], and acetone [10]. The aims of these studies were to elucidate the effect of the additional substituent on the parent molecule and the nucleophilicity and also the steric hindrance of the solvent molecule on the rate and diastereoselectivity of the reaction. Among the nucleophiles studied, only the reaction in the presence of cyclohexanone resulted in the formation of a single diastereomer. The reason is possibly the steric hindrance of cyclohexanone compared to other nucleophiles in the attack on the proposed reaction intermediates from the less hindered side [8]. In continuation of these studies, we have investigated the photocatalytic ring opening of certain $\alpha$-epoxyketones by TPT in cyclopentanone to elucidate the effect of the nature and the steric hindrance of the nucleophile on the diastereoselectivity of the reaction.

\section{Results and Discussion}

Irradiation $(\lambda \geq 400 \mathrm{~nm})$ of $\alpha$-epoxyketones $\mathbf{1 a}-$ $\mathbf{h}$ and the photocatalyst $\mathbf{2}$ in a molar ratio of $10: 1$ in cyclopentanone/dry acetonitrile $(19 \mathrm{~mL} / 1 \mathrm{~mL})$ resulted in the opening of the epoxide ring and formation of the diastereomeric spiro-1,3-dioxolanes $3 \mathbf{a}-\mathbf{e}, \mathbf{4 a}-$ $\mathbf{e}, \mathbf{4 g}, \mathbf{h}$, of the $\beta$-diketone $\mathbf{5}$, the cis- $\alpha$-epoxyketone $\mathbf{6 g}$, and also of the chalcones $\mathbf{7 e , f}, \mathbf{h}$ (Scheme 1). It should 
<smiles>[R]c1ccc(C(=O)[C@@H]2O[C@H]2c2ccc([R])cc2)cc1</smiles>

\begin{tabular}{c|cc}
$\mathbf{1}$ & $\mathrm{R}^{1}$ & $\mathrm{R}^{2}$ \\
\hline $\mathbf{a}$ & $\mathrm{H}$ & $\mathrm{H}$ \\
$\mathbf{b}$ & $\mathrm{H}$ & $\mathrm{CH}_{3}$ \\
$\mathbf{c}$ & $\mathrm{CH}_{3}$ & $\mathrm{H}$ \\
$\mathbf{d}$ & $\mathrm{H}$ & $\mathrm{OCH}_{3}$ \\
$\mathbf{e}$ & $\mathrm{OCH}_{3}$ & $\mathrm{H}$ \\
$\mathbf{f}$ & $\mathrm{OCH}_{3}$ & $\mathrm{OCH}_{3}$ \\
$\mathbf{g}$ & $\mathrm{H}$ & $\mathrm{Cl}$ \\
$\mathbf{h}$ & $\mathrm{Cl}$ & $\mathrm{H}$
\end{tabular}<smiles>[R]c1ccc(C(=O)[C@H]2OC3(CCCO3)O[C@H]2c2ccc([R4])cc2)cc1</smiles><smiles>O=C(CC(=O)c1ccc(Cl)cc1)c1ccccc1</smiles><smiles>O=C(c1ccccc1)[C@H]1O[C@H]1c1ccc(Cl)cc1</smiles><smiles>[R]c1ccc(/C=C/C(=O)c2ccc([R4])cc2)cc1</smiles><smiles>[R]c1ccc(C(=O)[C@H]2OC3(CCCCC3)O[C@H]2c2ccc([R])cc2)cc1</smiles>
a: $\mathrm{R}^{1}=\mathrm{OCH}_{3}, \mathrm{R}^{2}=\mathrm{H}$ b: $\mathrm{R}^{1}=\mathrm{OCH}_{3}, \mathrm{R}^{2}=\mathrm{OCH}_{3}$ c: $\mathrm{R}^{1}=\mathrm{Cl}, \mathrm{R}^{2}=\mathrm{H}$

Scheme 1.

Table 1. Photochemical reaction of $\mathbf{1 a}-\mathbf{h}$ catalyzed by $\mathbf{2}$ in cyclopentanone solution ${ }^{\mathrm{a}}$.

\begin{tabular}{lccccccc}
\hline & & \multicolumn{7}{c}{ Products (yield in \%) } \\
$\mathbf{1}$ & Irrad. time (h) & $\mathbf{3}$ & $\mathbf{4}$ & $\mathbf{1}$ & $\mathbf{6}$ & $\mathbf{5}$ & $\mathbf{7}$ \\
\hline $\mathbf{a}$ & 8 & $22(33)$ & $27(40)$ & 32 & - & - & - \\
$\mathbf{b}$ & 5 & $24(35)$ & $28(40)$ & 31 & - & - & - \\
$\mathbf{c}$ & 7 & $22(32)$ & $27(42)$ & 32 & - & - & - \\
$\mathbf{d}$ & 2 & $23(34)$ & $29(41)$ & 31 & - & - & - \\
$\mathbf{e}$ & 6 & $18(34)$ & $22(40)$ & 32 & - & - & $14(20)$ \\
$\mathbf{f}$ & 7 & - & - & 41 & - & - & $42(72)$ \\
$\mathbf{g}$ & 11 & - & $35(50)$ & 30 & $24(35)$ & - & - \\
$\mathbf{h}$ & 9 & - & $26(39)$ & 20 & - & $32(48)$ & $14(18)$ \\
a & \\
Molar ratio of $\mathbf{1 a}-\mathbf{h}: \mathbf{2}$ was $10: 1 ;{ }^{\text {b }}$ isolated yields based on used 1
\end{tabular}

be mentioned that for selective excitation of $\mathbf{2}$, the light was passed through a filter solution to prevent the absorption of light by compounds $\mathbf{1 a}-\mathbf{h}$. The results are summarized in Table 1.

The results obtained in the present study and especially in comparison to those obtained on irradiation in cyclohexanone [8] show that the substituted $\alpha$-epoxyketones $\mathbf{1 a}-\mathbf{h}$ behave totally different in the reaction. Whereas the reaction of $\mathbf{1 a}-\mathbf{e}$ in the presence of $\mathbf{2}$ in cyclohexanone resulted in the formation of solely the cis-diastereomeric 2,5-dioxaspiro[4,5]decanes 8ae (Scheme 1), the formation of cis- and trans-2,5-dioxaspiro[4,5]nonanes $3 \mathbf{a}-\mathbf{e}, \mathbf{4 a}-\mathbf{e}$ and $\mathbf{4 g}, \mathbf{h}$ and other products has been observed upon irradiation in cyclopentanone.

IR and ${ }^{1} \mathrm{H}$ NMR data have provided useful information for the structural assignment of the products. Monitoring of the photoreaction (conversion of $\mathbf{1 a}-\mathbf{e}, \mathbf{1 g}-\mathbf{h}$ and formation of $3 \mathbf{a}-\mathbf{e}, 4 \mathbf{a}-\mathbf{e}, 4 \mathbf{g}-\mathbf{h}$ ) was carried out by IR spectroscopy, which showed a the shift of the $\mathrm{CO}$ band of the aroyl group to higher frequency due to the opening of the epoxide ring and release of the ring strain, and the appearance of the aliphatic $\mathrm{CH}$ stretching vibration (2850$2950 \mathrm{~cm}^{-1}$ ) because of addition of cyclopentanone. 


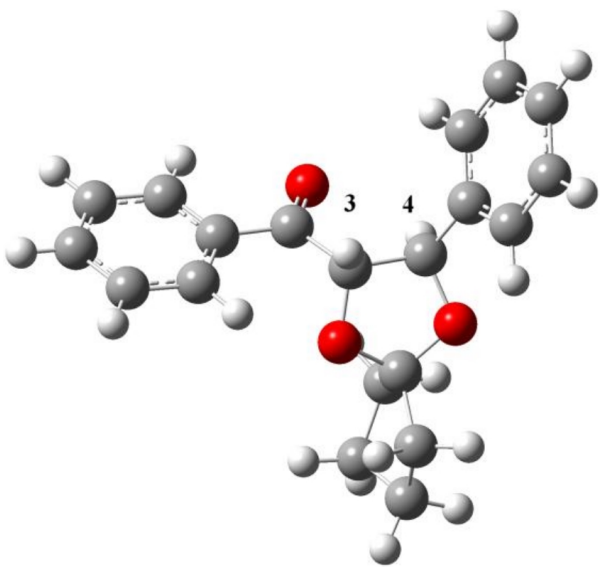

$\mathrm{H}^{3}-\mathrm{C}^{3}-\mathrm{C}^{4}-\mathrm{H}^{4}=145.25^{\circ}$

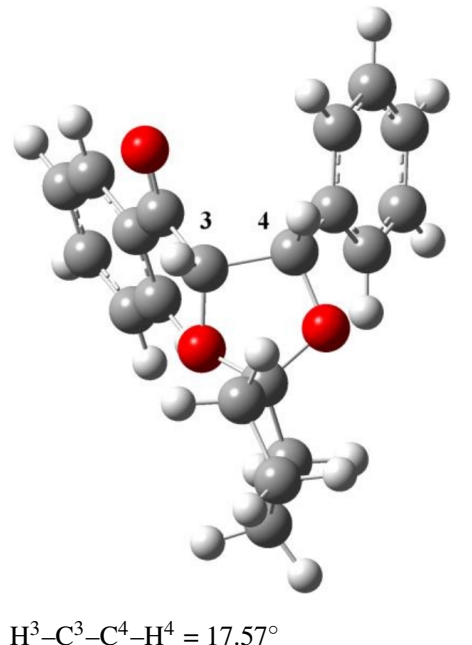

$\mathrm{H}^{3}-\mathrm{C}^{3}-\mathrm{C}^{4}-\mathrm{H}^{4}=17.57^{\circ}$

Fig. 1. The optimized structures of 3a (trans-product) and $\mathbf{4 a}$ (cis-product) obtained at the B3LYP/6-31++G(d,p) level of theory.

Table 2. Comparison of the carbonyl stretching vibration in the IR spectra $\left(v / \mathrm{cm}^{-1}\right)$ of compounds $\mathbf{1}, \mathbf{3}$, and $\mathbf{4}$.

\begin{tabular}{cccccc}
\hline $\mathbf{1}$ & $v(\mathrm{C}=\mathrm{O})$ & $\mathbf{3}$ & $v(\mathrm{C}=\mathrm{O})$ & $\mathbf{4}$ & $v(\mathrm{C}=\mathrm{O})$ \\
\hline $\mathbf{a}$ & 1670 & $\mathbf{a}$ & 1680 & $\mathbf{a}$ & 1688 \\
$\mathbf{b}$ & 1660 & $\mathbf{b}$ & 1681 & $\mathbf{b}$ & 1697 \\
$\mathbf{c}$ & 1665 & $\mathbf{c}$ & 1690 & $\mathbf{c}$ & 1690 \\
$\mathbf{d}$ & 1660 & $\mathbf{d}$ & 1690 & $\mathbf{d}$ & 1696 \\
$\mathbf{e}$ & 1665 & $\mathbf{e}$ & 1682 & $\mathbf{e}$ & 1686 \\
$\mathbf{g}$ & 1665 & - & - & $\mathbf{g}$ & 1695 \\
$\mathbf{h}$ & 1670 & - & - & $\mathbf{h}$ & 1695 \\
\hline
\end{tabular}

Table 3. Characteristic ${ }^{1} \mathrm{H}$ chemical shifts $(\delta / \mathrm{ppm})$ and ${ }^{3} J$ coupling constants $(J / H z)$ in the ${ }^{1} \mathrm{H}$ NMR spectra of the trans- $(\mathbf{3 a}-\mathbf{e})$ and the cis-products $(\mathbf{4 a}-\mathbf{e}$ and $\mathbf{4 g}, \mathbf{h})$.

\begin{tabular}{cccccccc}
\hline $\mathbf{3}$ & $\delta_{\mathrm{A}}$ & $\delta_{\mathrm{B}}$ & $J_{\mathrm{AB}}$ & $\mathbf{4}$ & $\delta_{\mathrm{A}}$ & $\delta_{\mathrm{B}}$ & $J_{\mathrm{AB}}$ \\
\hline $\mathbf{a}$ & 5.00 & 5.42 & 7.2 & $\mathbf{a}$ & 5.57 & 5.84 & 8.0 \\
$\mathbf{b}$ & 4.97 & 5.34 & 7.2 & $\mathbf{b}$ & 5.54 & 5.80 & 8.0 \\
$\mathbf{c}$ & 4.98 & 5.41 & 7.2 & $\mathbf{c}$ & 5.56 & 5.81 & 8.0 \\
$\mathbf{d}$ & 4.99 & 5.31 & 7.2 & $\mathbf{d}$ & 5.43 & 5.67 & 7.6 \\
$\mathbf{e}$ & 4.96 & 5.41 & 7.2 & $\mathbf{e}$ & 5.45 & 5.65 & 8.0 \\
& & & & $\mathbf{g}$ & 5.67 & 6.08 & 8.0 \\
& & & & $\mathbf{h}$ & 5.46 & 5.61 & 8.0 \\
\hline
\end{tabular}

A comparison of the $\mathrm{CO}$ frequencies is shown in Table 2.

${ }^{1} \mathrm{H}$ NMR spectra were helpful for the stereochemical assignment of the isomeric dioxolanes (Table 3). An AB system for protons $3-\mathrm{H}$ and $4-\mathrm{H}$ of the dioxolane ring was observed at $\delta=4.96-6.08 \mathrm{ppm}$. According to the Karplus-Conroy equation, and using the Karplus diagram [20], a larger coupling constant is expected for $3-\mathrm{H}$ and $4-\mathrm{H}$ in the cis-products $(\mathbf{4 a}-\mathbf{e}$ and $\mathbf{4 g}, \mathbf{h})$. The chemical shifts for $3-\mathrm{H}$ and $4-\mathrm{H}$ of $\mathbf{4 a}-\mathbf{e}, \mathbf{4 g}, \mathbf{h}$ (cis-products) are closer to each other in comparison to those of $\mathbf{3 a}-\mathbf{e}$ (trans-products), and the chemical shifts of the aromatic protons are closer and appear at higher field for the $c i s$-isomer, which is possibly due to the parallel alignment of the aromatic rings.

Density functional theory at the B3LYP/6-31++G** level was applied to study structural, electronic, and bonding characteristics of the photoproducts. The analysis showed that $4-\mathrm{H}$ is located in the plane of the phenyl ring, whereas $3-\mathrm{H}$ lies parallel to the phenyl ring of the benzoyl moiety (Fig. 1). This causes a deshielding of 4-H and a shielding of 3-H, respectively. The dihedral angle formed by $\mathrm{H}^{3}-\mathrm{C}^{3}-\mathrm{C}^{4}-\mathrm{H}^{4}$ in both isomers support the observed different coupling constants. All these theoretical data confirm the assumed assignments.

Due to the failure of the ring opening reaction of $\alpha$ epoxyketones in the absence of light and photocatalyst, we have proposed a mechanism involving an electron transfer-induced ring opening in the presence of various photocatalysts [7]. The proposed electron transfer from $\alpha$-epoxyketones to the electronically excited photocatayst leads to the formation of three different radical cation intermediates 9-11 (Scheme 2). Their stability and their involvement in the reaction depend on the location of the additional substituent in the parent molecule 1a. The attack of a suitable nucleophilic solvent to the proposed intermediates either from the upper side or the lower side accomplishes the reaction. This indicates also that the size and the nucleophilic strength of the solvent molecule can explain the observed diastereoselectivity and the rate of reaction. 
<smiles>[R]c1ccc(C(=O)[C@]2([Z17])[O+][C@H]2c2ccc([R])cc2)cc1</smiles>

9<smiles>[R]c1ccc(C(=O)[C@@H]2[C@@H]([OH2+])[C@@H]2c2ccc([R])cc2)cc1</smiles>

10<smiles>[R]c1ccc(C(=O)C([O])[C@@H](O)c2ccc([R])cc2)cc1</smiles>

11
Scheme 2.
The interesting results in the present study, especially compared with the reaction in cyclohexanone solution, indicate that due to the smaller size of cyclopentanone, a nucleophilic attack at both sides to the reaction intermediates leads to the formation of both diastereomers 3 and $\mathbf{4}$. The results show also that the preferred attack of cyclopentanone at the reaction intermediates occurs from the less-hindered side to from the cis-isomers $\mathbf{4 a}-\mathbf{e}$ and $\mathbf{4 g}, \mathbf{h}$, and that the electronic nature of the $\alpha$-epoxyketone depending on the location of the additional substituent in the parent molecule 1a explains its effect on the required time of irradiation.

The photoisomerization of trans- $\alpha$-epoxyketones to the corresponding cis-compounds has been explained with heterolytic $\mathrm{C}_{\alpha}-\mathrm{O}$ bond cleavage [21]. Recently, we have reported the same photoisomerization, but in the presence of 1-benzyl-2,4,6-triphenylpyridinium tetrafluoroborate (NBTPT) as photocatalyst [11]. The same mechanism is proposed for the photoisomerization of $\mathbf{1 g}$ in the presence of the photocatalyst $\mathbf{2}$ to the corresponding cis- $\alpha$-epoxyketone 6 in this study.
Another result of this study is the deoxygenation of some $\alpha$-epoxyketones to the corresponding chalcones. The same reaction also occurs by irradiation of these compounds in the presence of 1-benzyl-2,4,6-triphenylpyridinium tetrafluoroborate (NBTPT) as photocatalyst [11]. We have observed again the same reaction in the presence of the photocatalyst $\mathbf{2}$ for the formation of the chalcones $\mathbf{7 e}, \mathbf{f}, \mathbf{h}$.

Another interesting result in the present study is the conversion of $\mathbf{1 h}$ to $\mathbf{5}$. Photorearrangement of compound $\mathbf{1 h}$ to the $\beta$-diketone $\mathbf{5}$ has already been reported upon irradiation (Scheme 3a) [22]. Since the light has been passed through the filter solution to avoid direct excitation of $\alpha$-epoxyketones, we can propose a mechanism, in which the photocatalyst is involved in the conversion (Scheme 3b).

According to the proposed mechanism, $\mathrm{C}_{\alpha}-\mathrm{O}$ cleavage of the complex leads to the formation of a radical cation intermediate. Back electron transfer (BET) to this intermediate gives the 1,3-carbo-oxy diradical, the same diradical intermediate proposed to be pro-

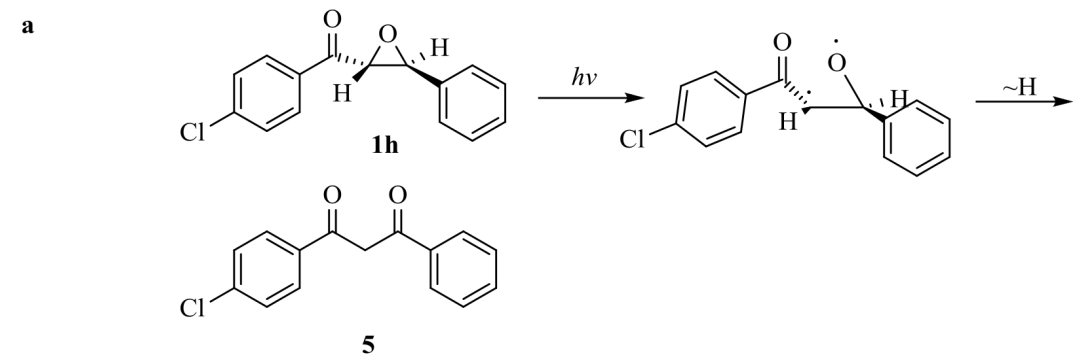

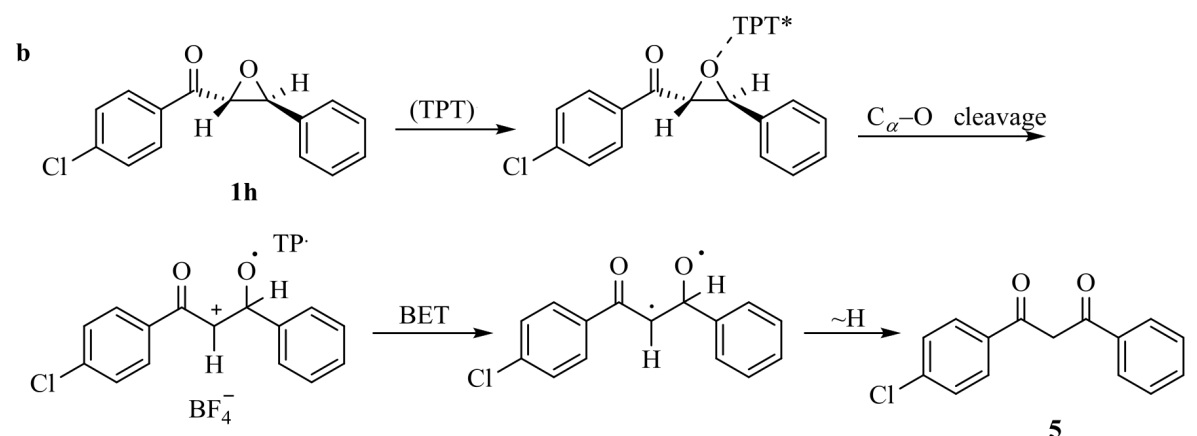

Scheme 3. TPT: 2,4,6-triphenylpyrylium tetrafluoroborate; BET: back electron transfer. 
duced by direct irradiation of $\mathbf{1 h}$. Hydrogen shift in this intermediate accomplishes the reaction under formation of the $\beta$-diketone $\mathbf{5}$.

\section{Conclusion}

In conclusion, we have found that due to the smaller size of cyclopentanone compared with cyclohexanone, nucleophilic attack of the former at the proposed reaction intermediates results in the formation of diastereomeric spiro-1,3-dioxolanes. The formation of cis- $\alpha$-epoxyketones, chalcones and $\beta$-diketones has also been observed in the present study.

\section{Experimental Section}

Melting points were determined with a Stuart Scientific SMP2-apparatus and are uncorrected. IR spectra were recorded using $\mathrm{KBr}$ pellets on a Jasco FT/IR-6300 spectrometer. ${ }^{1} \mathrm{H}$ NMR spectra were recorded on a Bruker $400 \mathrm{MHz}$ spectrometer in $\mathrm{CDCl}_{3}$ and $\left[\mathrm{D}_{6}\right] \mathrm{DMSO}$ with TMS as internal standard. Mass spectra were measured by electron impact at $70 \mathrm{eV}$ on a Micromass Platform II instrument. Preparative thin layer chromatography (PTLC) was carried out on $20 \times 20 \mathrm{~cm}^{2}$ plates, coated with a $1 \mathrm{~mm}$ layer of Merck silica gel $\mathrm{PF}_{254}$, prepared by applying the silica as slurry and drying in air. All irradiations were carried out using a $400 \mathrm{~W}$ high-pressure Hg lamp from NARVA in Duran glass equipment. The light was passed through a filter solution (75 $\mathrm{g} \mathrm{L}^{-1}$ of $\mathrm{NaNO}_{2}$ and $4.4 \mathrm{~g} \mathrm{~L}^{-1}$ of $\mathrm{CuSO}_{4}$ in $2.7 \mathrm{M}$ $\mathrm{NH}_{4} \mathrm{OH}$ ) [23] to obtain $\lambda \geq 400 \mathrm{~nm}$ for the selective excitation of the photocatalyst $\mathbf{2}$ and also to prevent the absorption of the light by $\mathbf{1 a}-\mathbf{h}$.

To a solution of $0.08 \mathrm{mmol}$ of $\mathbf{2}$ in dry acetonitrile $(1 \mathrm{~mL})$ and cyclopentanone $(19 \mathrm{~mL})(c=0.004 \mathrm{M})$ was added $0.8 \mathrm{mmol}$ of an $\alpha$-epoxyketone $\mathbf{1 a}-\mathbf{h}(c=0.04 \mathrm{M})$, and the mixtures were irradiated until maximum progression of the reaction was observed. The irradiation times are given in Table 1 . The excess of cyclopentanone was evaporated under reduced pressure, and the residue was purified by preparative TLC (PTLC).

\section{Irradiation of trans-1,3-diphenyl-2,3-epoxy-1-propanone (1a)}

PLC, petroleum ether:ethyl acetate $=15: 2$, two times; zone $1\left(R_{\mathrm{f}}=0.71\right), 39 \mathrm{mg}$ ( $33 \%$ based on consumed 1a and $22 \%$ based on used 1a) of 3a, washed with $n$-hexane; m. p.: $103-105^{\circ} \mathrm{C}$.

trans-3-Benzoyl-4-phenyl-2,5-dioxaspiro[4,4]nonane (3a)

IR: $v=3068,2963-2869,1680,1595,1218$, $1110 \mathrm{~cm}^{-1} \cdot-{ }^{1} \mathrm{H}$ NMR $\left(400 \mathrm{MHz}, \mathrm{CDCl}_{3}\right): \delta=1.74-$ $2.16(\mathrm{~m}, 8 \mathrm{H}$, cyclopentane $\mathrm{H}), \mathrm{AB}$ system $\left(\delta_{\mathrm{A}}=5.00, \delta_{\mathrm{B}}=\right.$ $\left.5.42,{ }^{3} J_{\mathrm{AB}}=7.2 \mathrm{~Hz}, 2 \mathrm{H}, 3-\mathrm{H}, 4-\mathrm{H}\right), 7.40\left(\mathrm{~m}_{\mathrm{c}}, 7 \mathrm{H}\right.$, phenyl $\mathrm{H}$ and $2 m-\mathrm{H}$ of $\mathrm{PhCO}), 7.56\left(\mathrm{~m}_{\mathrm{c}}, 1 \mathrm{H}, p-\mathrm{H}\right.$ of $\left.\mathrm{PhCO}\right)$, $7.92(\mathrm{~d}, J=8.4 \mathrm{~Hz}, 2 \mathrm{H}, 2 o-\mathrm{H}$ of $\mathrm{PhCO}) .-\mathrm{MS}$ (EI, $70 \mathrm{eV}): m / z(\%)=308(3)[\mathrm{M}]^{+}, 224(93)\left[\mathrm{M}-\mathrm{C}_{5} \mathrm{H}_{8} \mathrm{O}\right]^{+}$, $203(100)\left[\mathrm{M}-\mathrm{C}_{6} \mathrm{H}_{5} \mathrm{CO}\right]^{+}, 202(66)\left[\mathrm{M}-\mathrm{C}_{6} \mathrm{H}_{5} \mathrm{CHO}\right]^{+}, 119$ (98) $\left[\mathrm{C}_{6} \mathrm{H}_{5} \mathrm{COCH}_{2}\right]^{+}, 105$ (100) $\left[\mathrm{C}_{6} \mathrm{H}_{5} \mathrm{CO}\right]^{+}, 91$ (89) $\left[\mathrm{C}_{6} \mathrm{H}_{5} \mathrm{CH}_{2}\right]^{+}, 77(90)\left[\mathrm{C}_{6} \mathrm{H}_{5}\right]^{+}$; zone $2: R_{\mathrm{f}}=0.52$, recovered 1a $\left(56 \mathrm{mg}, 32 \%\right.$ based on used 1a); zone $3\left(R_{\mathrm{f}}=0.49\right)$, $48 \mathrm{mg}$ ( $40 \%$ based on consumed and $27 \%$ based on used 1a) of $\mathbf{4 a}$, recrystallized from $n$-hexane/ethyl acetate; m. p.: 122 $125^{\circ} \mathrm{C}$.

cis-3-Benzoyl-4-phenyl-2,5-dioxaspiro[4,4]nonane (4a)

IR: $v=3070, \quad 2982-2940, \quad 1688,1597,1269$, $1208 \mathrm{~cm}^{-1} .-{ }^{1} \mathrm{H}$ NMR $\left(400 \mathrm{MHz}, \mathrm{CDCl}_{3}\right): \delta=1.58$ $\left(\mathrm{m}_{\mathrm{c}}, 4 \mathrm{H}\right.$, cyclopentane $\left.\mathrm{H}\right), 1.88$ (brd s, $4 \mathrm{H}$, cyclopentane $\left.\mathrm{H}\right)$, $\mathrm{AB}$ system $\left(\delta_{\mathrm{A}}=5.57, \delta_{\mathrm{B}}=5.84,{ }^{3} J_{\mathrm{AB}}=8.0 \mathrm{~Hz}, 2 \mathrm{H}, 3-\mathrm{H}\right.$, 4-H), $7.10\left(\mathrm{~m}_{\mathrm{c}}, 4 \mathrm{H}\right.$, aromatic $\left.\mathrm{H}\right), 7.25\left(\mathrm{~m}_{\mathrm{c}}, 3 \mathrm{H}\right.$, aromatic $\mathrm{H}), 7.39\left(\mathrm{~m}_{\mathrm{c}}, 1 \mathrm{H}, p-\mathrm{H}\right.$ of $\left.\mathrm{PhCO}\right), 7.47(\mathrm{~d}, J=6.8 \mathrm{~Hz}, 2$ $o$-H of PhCO). - MS (EI, $70 \mathrm{eV}): m / z(\%)=308(4)[\mathrm{M}]^{+}$, 224 (97) $\left[\mathrm{M}-\mathrm{C}_{5} \mathrm{H}_{8} \mathrm{O}\right]^{+}, 203(97)\left[\mathrm{M}-\mathrm{C}_{7} \mathrm{H}_{5} \mathrm{O}\right]^{+}, 202(74)$ $\left[\mathrm{M}-\mathrm{C}_{6} \mathrm{H}_{5} \mathrm{CHO}\right]^{+}, 119$ (94) $\left[\mathrm{C}_{6} \mathrm{H}_{5} \mathrm{COCH}_{2}\right]^{+}, 105$ (100) $\left[\mathrm{C}_{6} \mathrm{H}_{5} \mathrm{CO}\right]^{+}, 91(88)\left[\mathrm{C}_{6} \mathrm{H}_{5} \mathrm{CH}_{2}\right]^{+}, 89(80)\left[\mathrm{C}_{7} \mathrm{H}_{5}\right]^{+}, 77$ (92) $\left[\mathrm{C}_{6} \mathrm{H}_{5}\right]^{+}$.

Irradiation of trans-3-p-methylphenyl-1-phenyl-2,3-epoxy1-propanone $(\mathbf{l b})$

PLC, petroleum ether:ethyl acetate $=15: 2$, two times; zone $1\left(R_{\mathrm{f}}=0.74\right), 46 \mathrm{mg}(35 \%$ based on consumed $\mathbf{1 b}$ and $24 \%$ based on used $\mathbf{1 b}$ ) of $\mathbf{3 b}$, washed with $n$-hexane; m. p.: $111-115{ }^{\circ} \mathrm{C}$.

\section{trans-3-Benzoyl-4-(p-methylphenyl)-2,5-dioxaspiro-}

$[4,4]$ nonane $(3 \boldsymbol{b})$

IR: $v=2962,2862,1681,1595,1218,1110 \mathrm{~cm}^{-1} .-$ ${ }^{1} \mathrm{H}$ NMR $\left(400 \mathrm{MHz}, \mathrm{CDCl}_{3}\right): \delta=1.93\left(\mathrm{~m}_{\mathrm{c}}, 8 \mathrm{H}\right.$, cyclopentane $\mathrm{H}), 2.34\left(\mathrm{~s}, 3 \mathrm{H}, \mathrm{CH}_{3}\right), \mathrm{AB}$ system $\left(\delta_{\mathrm{A}}=4.97\right.$, $\left.\delta_{\mathrm{B}}=5.34,{ }^{3} J_{\mathrm{AB}}=7.2 \mathrm{~Hz}, 2 \mathrm{H}, 3-\mathrm{H}, 4-\mathrm{H}\right), 7.24\left(\mathrm{~m}_{\mathrm{c}}, 5 \mathrm{H}\right.$, $p-\mathrm{H}$ of PhCO and phenyl $\mathrm{H}), 7.41\left(\mathrm{~m}_{\mathrm{c}}, 2 \mathrm{H}, 2 \mathrm{~m}-\mathrm{H}\right.$ of PhCO), $7.91\left(\mathrm{~m}_{\mathrm{c}}, 2 \mathrm{H}, 2 \mathrm{o}-\mathrm{H}\right.$ of PhCO). - MS (EI, $\left.70 \mathrm{eV}\right)$ : $m / z(\%)=238$ (7) $[\mathrm{M}-\text { cyclopentanone }]^{+}, 147$ (3) $[\mathrm{M}-$ cyclopentanone- $\left.\mathrm{CH}_{3} \mathrm{C}_{6} \mathrm{H}_{4}\right]^{+}, 134$ (10) $[\mathrm{PhCOCHO}]^{+}, 105$ (100) $\left[\mathrm{C}_{6} \mathrm{H}_{5} \mathrm{CO}\right]^{+}, 91(23)\left[\mathrm{CH}_{3} \mathrm{C}_{6} \mathrm{H}_{4}\right]^{+}, 77(85)\left[\mathrm{C}_{6} \mathrm{H}_{5}\right]^{+}$; zone 2: $R_{\mathrm{f}}=0.54$, recovered $\mathbf{1 b}(59 \mathrm{mg}, 31 \%$ based on used $1 \mathrm{~b})$; zone $3\left(R_{\mathrm{f}}=0.46\right), 53 \mathrm{mg}(40 \%$ based on consumed $\mathbf{1 b}$ and $28 \%$ based on used $\mathbf{1 b}$ ) of $\mathbf{4 b}$, recrystallized from $n$-hexane/ethyl acetate; m. p.: $145-148^{\circ} \mathrm{C}$.

cis-3-Benzoyl-4-(p-methylphenyl)-2,5-dioxaspiro$[4,4]$ nonane $(\mathbf{4 b})$

IR: $v=2922,1697,1216,1037 \mathrm{~cm}^{-1} .-{ }^{1} \mathrm{H}$ NMR $\left(400 \mathrm{MHz}, \mathrm{CDCl}_{3}\right): \delta=1.59-1.86\left(\mathrm{~m}_{\mathrm{c}}, 8 \mathrm{H}\right.$, cyclopen- 
tane $\mathrm{H}), 2.16\left(\mathrm{~s}, 3 \mathrm{H}, \mathrm{CH}_{3}\right), \mathrm{AB}$ system $\left(\delta_{\mathrm{A}}=5.53, \delta_{\mathrm{B}}=\right.$ $\left.5.79,{ }^{3} J_{\mathrm{AB}}=8.0 \mathrm{~Hz}, 2 \mathrm{H}, 3-\mathrm{H}, 4-\mathrm{H}\right), 6.84(\mathrm{~d}, J=8.4 \mathrm{~Hz}$, $2 \mathrm{H}, 2 o-\mathrm{H}$ of phenyl), $6.98\left(\mathrm{~m}_{\mathrm{c}}, 2 \mathrm{H}, 2 \mathrm{~m}-\mathrm{H}\right.$ of phenyl), $7.26\left(\mathrm{~m}_{\mathrm{c}}, 3 \mathrm{H}, 2 \mathrm{~m}-\mathrm{H}\right.$ and $p-\mathrm{H}$ of $\left.\mathrm{PhCO}\right), 7.48(\mathrm{~d}, J=$ $6.8 \mathrm{~Hz}, 2 \mathrm{H}, 2 \mathrm{o}-\mathrm{H}$ of PhCO). - MS (EI, $70 \mathrm{eV}): \mathrm{m} / z(\%)=$ 238 (9) $[\mathrm{M}-\text { cyclopentanone }]^{+}, 134(8)\left[\mathrm{C}_{6} \mathrm{H}_{5} \mathrm{COCHO}^{+}\right.$, $133(21)\left[\mathrm{C}_{6} \mathrm{H}_{5} \mathrm{COCO}\right]^{+}, 105(100)\left[\mathrm{C}_{6} \mathrm{H}_{5} \mathrm{CO}\right]^{+}, 91(22)$ $\left[\mathrm{CH}_{3} \mathrm{C}_{6} \mathrm{H}_{4}\right]^{+}, 77(86)\left[\mathrm{C}_{6} \mathrm{H}_{5}\right]^{+}$.

Irradiation of trans-1-p-methylphenyl-3-phenyl-2,3-epoxy1-propanone $(1 \mathrm{c})$

PLC, petroleum ether:ethyl acetate $=15: 2$, two times; zone $1\left(R_{\mathrm{f}}=0.72\right), 42 \mathrm{mg}$ ( $32 \%$ based on consumed 1c and $22 \%$ based on used $1 \mathbf{c})$ of $\mathbf{3 c}$ as a viscous oil.

trans-3-(p-Methylbenzoyl)-4-phenyl-2,5-dioxaspiro$[4,4]$ nonane $(3 \mathrm{c})$

IR: $\quad v=3032,2992-2936,1690,1607,1208$, $1100 \mathrm{~cm}^{-1} .-{ }^{1} \mathrm{H}$ NMR (400 MHz, $\left.\mathrm{CDCl}_{3}\right): \delta=1.75-1.90$ $(2 \mathrm{~m}, 8 \mathrm{H}$, cyclopentane $\mathrm{H}), 2.41\left(\mathrm{~s}, 3 \mathrm{H}, \mathrm{CH}_{3}\right), \mathrm{AB}$ system $\left(\delta_{\mathrm{A}}=4.98, \delta_{\mathrm{B}}=5.41,{ }^{3} J_{\mathrm{AB}}=7.2 \mathrm{~Hz}, 2 \mathrm{H}, 3-\mathrm{H}, 4-\mathrm{H}\right), 7.21$ (d, $J=8 \mathrm{~Hz}, 2 \mathrm{H}, 2 o-\mathrm{H}$ of phenyl), $7.37\left(\mathrm{~m}_{\mathrm{c}}, 4 \mathrm{H}, m-\mathrm{H}\right.$ of phenyl and ArCO), $7.45(\mathrm{~d}, J=6.8 \mathrm{~Hz}, 1 \mathrm{H}, p-\mathrm{H}$ of phenyl), 7.82 (d, $J=7.6 \mathrm{~Hz}, 2 \mathrm{H}, 2 o-\mathrm{H}$ of ArCO). - MS (EI, $70 \mathrm{eV}): m / z(\%)=238(36)[\mathrm{M} \text {-cyclopentanone }]^{+}, 203$ (11) $\left[\mathrm{M}-\mathrm{CH}_{3} \mathrm{C}_{6} \mathrm{H}_{4} \mathrm{CO}\right]^{+}, 119$ (100) $\left[\mathrm{CH}_{3} \mathrm{C}_{6} \mathrm{H}_{4} \mathrm{CO}\right]^{+}, 105$ (6) $\left[\mathrm{C}_{6} \mathrm{H}_{4} \mathrm{CHO}\right]^{+}, 91(58)\left[\mathrm{CH}_{3} \mathrm{C}_{6} \mathrm{H}_{4}\right]^{+}, 77(10)\left[\mathrm{C}_{6} \mathrm{H}_{5}\right]^{+}$; zone 2: $R_{\mathrm{f}}=0.54$, recovered $1 \mathrm{c}(61 \mathrm{mg}, 32 \%$ based on used 1c); zone $3\left(R_{\mathrm{f}}=0.48\right), 54 \mathrm{mg}(42 \%$ based on consumed 1c and $27 \%$ based on used 1c) of $\mathbf{4 c}$, recrystallized from $n$-hexane/ethyl acetate; m. p.: $134-136^{\circ} \mathrm{C}$.

cis-3-(p-Methylbenzoyl)-4-phenyl-2,5-dioxaspiro[4,4]nonane (4c)

IR: $\quad v=3031,2992-2936, \quad 1690,1608,1210$, $1039 \mathrm{~cm}^{-1} .-{ }^{1} \mathrm{H}$ NMR (400 MHz, $\left.\mathrm{CDCl}_{3}\right): \delta=1.60$ (s, 5H, cyclopentane $\mathrm{H}), 1.86$ (s, 3H, cyclopentane $\mathrm{H}), 2.32$ $\left(\mathrm{s}, 3 \mathrm{H}, \mathrm{CH}_{3}\right), \mathrm{AB}$ system $\left(\delta_{\mathrm{A}}=5.56, \delta_{\mathrm{B}}=5.81,{ }^{3} J_{\mathrm{AB}}=\right.$ $8.0 \mathrm{~Hz}, 2 \mathrm{H}, 3-\mathrm{H}, 4-\mathrm{H}), 7.07\left(\mathrm{~m}_{\mathrm{c}}, 7 \mathrm{H}\right.$, phenyl $\mathrm{H}$ and $2 \mathrm{~m}-\mathrm{H}$ of ArCO), 7.41 (d, $J=7.6 \mathrm{~Hz}, 2 \mathrm{H}, 2 o-\mathrm{H}$ of ArCO). $-\mathrm{MS}$ $($ EI, $70 \mathrm{eV}): m / z(\%)=238(6)[\mathrm{M} \text {-cyclopentanone }]^{+}, 119$ (96) $\left[\mathrm{CH}_{3} \mathrm{C}_{6} \mathrm{H}_{4} \mathrm{CO}\right]^{+}, 105$ (13) $\left[\mathrm{C}_{6} \mathrm{H}_{4} \mathrm{CHO}\right]^{+}, 91$ (100) $\left[\mathrm{CH}_{3} \mathrm{C}_{6} \mathrm{H}_{4}\right]^{+}, 77(29)\left[\mathrm{C}_{6} \mathrm{H}_{5}\right]^{+}, 65(54)\left[\mathrm{C}_{5} \mathrm{H}_{5}\right]^{+}$.

Irradiation of trans-3-p-methoxyphenyl-1-phenyl-2,3-epoxy1-propanone $(\mathbf{l d})$

PLC, petroleum ether:ethyl acetate $=5: 2$, two times; zone $1\left(R_{\mathrm{f}}=0.69\right), 48 \mathrm{mg}$ ( $34 \%$ based on consumed 1d and $23 \%$ based on used 1d) of $\mathbf{3 d}$, washed with $n$-hexane; m. p.: $93-95^{\circ} \mathrm{C}$.
trans-3-Benzoyl-4-(p-methoxyphenyl)-2,5-dioxaspiro$[4,4]$ nonane $(3 d)$

IR: $\quad v=3031,2992-2935,1690,1607,1208$, $1039 \mathrm{~cm}^{-1} .-{ }^{1} \mathrm{H}$ NMR (400 MHz, $\mathrm{CDCl}_{3}$ ): $\delta=1.74-2.14$ ( $3 \mathrm{~m}, 8 \mathrm{H}$, cyclopentane $\mathrm{H}), 3.81\left(\mathrm{~s}, 3 \mathrm{H}, \mathrm{OCH}_{3}\right), \mathrm{AB}$ system $\left(\delta_{\mathrm{A}}=4.99, \delta_{\mathrm{B}}=5.31,{ }^{3} J_{\mathrm{AB}}=7.2 \mathrm{~Hz}, 2 \mathrm{H}, 3-\mathrm{H}, 4-\mathrm{H}\right)$, $6.89\left(\mathrm{~d}, J=8.0 \mathrm{~Hz}, 2 \mathrm{H}, 2 \mathrm{o}-\mathrm{H}\right.$ of phenyl), $7.38\left(\mathrm{~m}_{\mathrm{c}}, 4 \mathrm{H}\right.$, $2 m-\mathrm{H}$ of $\mathrm{PhCO}$ and $2 m-\mathrm{H}$ of phenyl), $7.55\left(\mathrm{~m}_{\mathrm{c}}, 1 \mathrm{H}, p-\mathrm{H}\right.$ of $\mathrm{PhCO}), 7.89(\mathrm{~d}, J=8.0 \mathrm{~Hz}, 2 \mathrm{H}, 2 o-\mathrm{H}$ of $\mathrm{PhCO})$. MS (EI, $70 \mathrm{eV}): m / z(\%)=338(2)[\mathrm{M}]^{+}, 231$ (2) $[\mathrm{M}-$ $\left.\mathrm{CH}_{3} \mathrm{OC}_{6} \mathrm{H}_{4}\right]^{+}, 149$ (11) [M-cyclopentanone- $\left.\mathrm{C}_{6} \mathrm{H}_{5} \mathrm{CO}\right]^{+}$, 135 (6) $\left[\mathrm{CH}_{3} \mathrm{OC}_{6} \mathrm{H}_{4} \mathrm{CO}\right]^{+}, 119$ (12) $\left[\mathrm{M}-\mathrm{CH}_{3} \mathrm{OC}_{6} \mathrm{H}_{4} \mathrm{CO}-\right.$ cyclopentanone $]^{+}, 105(13)\left[\mathrm{C}_{6} \mathrm{H}_{5} \mathrm{CO}\right]^{+}, 77(43)\left[\mathrm{C}_{6} \mathrm{H}_{5}\right]^{+}$; zone 2: $R_{\mathrm{f}}=0.52$, recovered $1 \mathrm{~d}(64 \mathrm{mg}, 31 \%$ based on used 1d); zone $3\left(R_{\mathrm{f}}=0.46\right), 59 \mathrm{mg}(41 \%$ based on consumed $1 \mathbf{d}$ and $29 \%$ based on used 1d) of $\mathbf{4 d}$, recrystallized from $n$-hexane/ethyl acetate; m. p.: $108-111^{\circ} \mathrm{C}$.

cis-3-Benzoyl-4-(p-methoxyphenyl)-2,5-dioxaspiro$[4,4]$ nonane $(\mathbf{4 d})$

IR: $v=2985-2921,1696,1514,1210,1037 \mathrm{~cm}^{-1} .-$ ${ }^{1} \mathrm{H}$ NMR $\left(400 \mathrm{MHz}, \mathrm{CDCl}_{3}\right): \delta=1.8-1.98(2 \mathrm{~m}, 8 \mathrm{H}$, cyclopentane $\mathrm{H}), 3.68\left(\mathrm{~s}, 3 \mathrm{H}, \mathrm{OCH}_{3}\right), \mathrm{AB}$ system $\left(\delta_{\mathrm{A}}=\right.$ $\left.5.43, \delta_{\mathrm{B}}=5.67,{ }^{3} J_{\mathrm{AB}}=7.6 \mathrm{~Hz}, 2 \mathrm{H}, 3-\mathrm{H}, 4-\mathrm{H}\right), 6.59$ (d, $J=8.0 \mathrm{~Hz}, 2 \mathrm{H}, 2 o-\mathrm{H}$ of phenyl), $7.01(\mathrm{~m}, 2 \mathrm{H}$, $2 m-\mathrm{H}$ of phenyl), $7.28(\mathrm{~m}, 3 \mathrm{H}, 2 m-\mathrm{H}$ and $p-\mathrm{H}$ of $\mathrm{PhCO}), 7.55$ (d, $J=7.2 \mathrm{~Hz}, 2 \mathrm{H}, 2 o-\mathrm{H}$ of $\mathrm{PhCO}) .-\mathrm{MS}$ $($ EI, $70 \mathrm{eV}): m / z(\%)=254(20)[\mathrm{M}-\text { cyclopentanone }]^{+}$, 203 (4) $\left[\mathrm{M}-\mathrm{CH}_{3} \mathrm{OC}_{6} \mathrm{H}_{4} \mathrm{CO}\right]^{+}, 202$ (19) $\left[\mathrm{M}-\mathrm{C}_{6} \mathrm{H}_{5} \mathrm{CO}-\right.$ $\left.\mathrm{OCH}_{3}\right]^{+}, 149$ (18) [M-cyclopentanone- $\left.\mathrm{C}_{6} \mathrm{H}_{5} \mathrm{CO}\right]^{+}, 135$ (7) $\left[\mathrm{CH}_{3} \mathrm{OC}_{6} \mathrm{H}_{4} \mathrm{CO}\right]^{+}, 107$ (4) $\left[\mathrm{CH}_{3} \mathrm{OC}_{6} \mathrm{H}_{4}\right]^{+}, 105$ (100) $\left[\mathrm{C}_{6} \mathrm{H}_{5} \mathrm{CO}\right]^{+}, 77(65)\left[\mathrm{C}_{6} \mathrm{H}_{5}\right]^{+}$.

Irradiation of trans-1-p-methoxyphenyl-3-phenyl-2,3-epoxy1-propanone (1e)

PLC, petroleum ether:ethyl acetate $=5: 2$, two times; zone $1\left(R_{\mathrm{f}}=0.78\right), 38 \mathrm{mg}$ ( $34 \%$ based on consumed 1e and $18 \%$ based on used $1 \mathbf{e})$ of $\mathbf{3 e}$ as a viscous oil.

trans-3-(p-Methoxybenzoyl)-4-phenyl-2,5-dioxaspiro[4,4]nonane (3e)

IR: $v=3067,2985-2918, \quad 1683,1560,1237$, $1061 \mathrm{~cm}^{-1}$. - ${ }^{1} \mathrm{H}$ NMR (400 MHz, $\mathrm{CDCl}_{3}$ ): $\delta=1.89-2.14$ $(3 \mathrm{~m}, 8 \mathrm{H}$, cyclopentane $\mathrm{H}), 3.87\left(\mathrm{~s}, 3 \mathrm{H}, \mathrm{OCH}_{3}, \mathrm{AB}\right.$ system $\left(\delta_{\mathrm{A}}=4.96, \delta_{\mathrm{B}}=5.41,{ }^{3} J_{\mathrm{AB}}=7.2 \mathrm{~Hz}, 2 \mathrm{H}, 3-\mathrm{H}, 4-\mathrm{H}\right), 6.88$ (d, $J=8.0 \mathrm{~Hz}, 2 \mathrm{H}, 2 \mathrm{~m}-\mathrm{H}$ of $\mathrm{PhCO}), 7.56\left(\mathrm{~m}_{\mathrm{c}}, 7 \mathrm{H}, 2 o-\mathrm{H}\right.$ of PhCO and phenyl H). - MS (EI, $70 \mathrm{eV}): m / z(\%)=254$ (7) $[\mathrm{M} \text {-cyclopentanone }]^{+}, 135$ (71) $\left[\mathrm{CH}_{3} \mathrm{OC}_{6} \mathrm{H}_{4} \mathrm{CO}\right]^{+}$, 119 (17) $\left[\mathrm{M}-\mathrm{CH}_{3} \mathrm{OC}_{6} \mathrm{H}_{4} \mathrm{CO}-\text { cyclopentanone }\right]^{+}, 105$ (4) $\left[\mathrm{C}_{6} \mathrm{H}_{4} \mathrm{CHO}\right]^{+}, 77(53)\left[\mathrm{C}_{6} \mathrm{H}_{5}\right]^{+}$; zone 2: $R_{\mathrm{f}}=0.59,28 \mathrm{mg}$ ( $20 \%$ based on consumed $1 \mathbf{e}$ and $14 \%$ based on used 1e) 7e; 
zone $3\left(R_{\mathrm{f}}=0.55\right)$ recovered $1 \mathrm{e}(66 \mathrm{mg}, 32 \%$ based on used 1e); zone $4\left(R_{\mathrm{f}}=0.45\right), 45 \mathrm{mg}(40 \%$ based on consumed $1 \mathrm{e}$ and $22 \%$ based on used $1 \mathbf{e})$ of $4 \mathbf{e}$, recrystallized from $n$-hexane/ethyl acetate; m. p.: $110-113{ }^{\circ} \mathrm{C}$.

cis-3-(p-Methoxybenzoyl)-4-phenyl-2,5-dioxaspiro[4,4]nonane (4e)

IR: $v=2954,1686,1576,1250,1183,1028 \mathrm{~cm}^{-1} .-$ ${ }^{1} \mathrm{H}$ NMR (400 MHz, $\left.\mathrm{CDCl}_{3}\right): \delta=1.82-2.32(\mathrm{~m}, 8 \mathrm{H}, \mathrm{cy}-$ clopentane $\mathrm{H}), 3.82\left(\mathrm{~s}, 3 \mathrm{H}, \mathrm{OCH}_{3}\right), \mathrm{AB}$ system $\left(\delta_{\mathrm{A}}=5.45\right.$, $\left.\delta_{\mathrm{B}}=5.65,{ }^{3} J_{\mathrm{AB}}=8.0 \mathrm{~Hz}, 2 \mathrm{H}, 3-\mathrm{H}, 4-\mathrm{H}\right), 6.75(\mathrm{~d}, J=8.4 \mathrm{~Hz}$, $2 \mathrm{H}, 2 \mathrm{~m}$-H of $\mathrm{ArCO}), 7.33\left(\mathrm{~m}_{\mathrm{c}}, 5 \mathrm{H}\right.$, phenyl $\left.\mathrm{H}\right), 7.84\left(\mathrm{~m}_{\mathrm{c}}, 2 \mathrm{H}\right.$, $2 o$-H of ArCO). - MS (EI, $70 \mathrm{eV}): m / z(\%)=254$ (6) [Mcyclopentanone $]^{+}, 135$ (100) $\left[\mathrm{CH}_{3} \mathrm{OC}_{6} \mathrm{H}_{4} \mathrm{CO}\right]^{+}, 119$ (19) $\left[\mathrm{M}-\mathrm{CH}_{3} \mathrm{OC}_{6} \mathrm{H}_{4} \mathrm{CO}\right]^{+}, 107$ (15) $\left[\mathrm{CH}_{3} \mathrm{OC}_{6} \mathrm{H}_{4}\right]^{+}, 77$ (51) $\left[\mathrm{C}_{6} \mathrm{H}_{5}\right]^{+}$.

Irradiation of trans-1,3-di(p-methoxyphenyl)-2,3-epoxy-1propanone (1f)

PLC, petroleum ether:ethyl acetate $=5: 1$, two times; zone $1\left(R_{\mathrm{f}}=0.72\right), 95 \mathrm{mg}$ (72\% based on consumed $\mathbf{1 f}$ and $42 \%$ based on used $\mathbf{1 f})$ of $\mathbf{7 f}$; zone $2\left(R_{\mathrm{f}}=0.56\right)$ recovered $\mathbf{1 f}$ (96 mg, $42 \%$ based on used 1f).

Irradiation of trans-3-p-chlorophenyl-1-phenyl-2,3-epoxy-1propanone (1g)

PLC, petroleum ether:ethyl acetate $=5: 2$, two times; zone $1\left(R_{\mathrm{f}}=0.70\right)$ recovered $1 \mathrm{~g}(64 \mathrm{mg}, 30 \%$ based on used $1 \mathrm{~g}$ ), zone $2: R_{\mathrm{f}}=0.50,51 \mathrm{mg}(35 \%$ based on consumed $1 \mathrm{~g}$ and $24 \%$ based on used $1 \mathrm{~g}) 6$.

cis-3-p-Chlorophenyl-1-phenyl-2,3-epoxy-1-propanone (6)

IR: $v=3087,1658,1576,1093 \mathrm{~cm}^{-1} .-{ }^{1} \mathrm{H} \mathrm{NMR}$ (400 MHz, [D 6 ]DMSO): $\delta=5.28$ (s, 2H, 3-H, 4-H), 7.41 $\left(\mathrm{m}_{\mathrm{c}}, 4 \mathrm{H}\right.$, phenyl), $7.48\left(\mathrm{~m}_{\mathrm{c}}, 2 \mathrm{H}, m-\mathrm{H}\right.$ of $\left.\mathrm{PhCO}\right), 7.64\left(\mathrm{~m}_{\mathrm{c}}\right.$, $1 \mathrm{H}, p-\mathrm{H}$ of $\mathrm{PhCO}), 7.88$ (d, $J=7.6 \mathrm{~Hz}, o-\mathrm{H}$ of $\mathrm{PhCO}) .-\mathrm{MS}$ $(\mathrm{EI}, 70 \mathrm{eV}): \mathrm{m} / z(\%)=258(4)\left[\mathrm{M},{ }^{35} \mathrm{Cl}\right]^{+}, 153(13)[\mathrm{M}-$ $\mathrm{PhCO}]^{+}, 111(5)\left[\mathrm{ClC}_{6} \mathrm{H}_{4}\right]^{+}, 105(73)\left[\mathrm{PhCO}^{+}, 77(100)\right.$ $\left[\mathrm{C}_{6} \mathrm{H}_{5}\right]^{+}$; zone $3\left(R_{\mathrm{f}}=0.44\right), 75 \mathrm{mg}(51 \%$ based on consumed $1 \mathrm{~g}$ and $35 \%$ based on used $\mathbf{1 g}$ ) of $\mathbf{4 g}$, recrystallized from $n$-hexane/ethyl acetate; m.p.: $126-129^{\circ} \mathrm{C}$.
cis-3-Benzoyl-4-(p-chlorophenyl)-2,5-dioxaspiro$[4,4]$ nonane $(\mathbf{4 g})$

IR: $\quad v=3049, \quad 2986-2936,1695,1577,1213$, $1039 \mathrm{~cm}^{-1} .-{ }^{1} \mathrm{H}$ NMR (400 MHz, [D 6 DMSO): $\delta=$ $1.52(\mathrm{~s}, 4 \mathrm{H}$, cyclopentane $\mathrm{H}), 1.70(\mathrm{~s}, 4 \mathrm{H}$, cyclopentane $\mathrm{H}), \mathrm{AB}$ system $\left(\delta_{\mathrm{A}}=5.67, \delta_{\mathrm{B}}=6.08,{ }^{3} J_{\mathrm{AB}}=8.0 \mathrm{~Hz}, 2 \mathrm{H}\right.$, 3-H, 4-H), $7.03(2 \mathrm{~m}, 5 \mathrm{H}$, aromatic $\mathrm{H}), 7.06\left(\mathrm{~m}_{\mathrm{c}}, 4 \mathrm{H}\right.$, phenyl $\mathrm{H} 0), 7.32\left(\mathrm{~m}_{\mathrm{c}}, 2 \mathrm{H}, 2 \mathrm{~m}-\mathrm{H}\right.$ of $\left.\mathrm{PhCO}\right), 7.49\left(\mathrm{~m}_{\mathrm{c}}, 1 \mathrm{H}, p-\mathrm{H}\right.$ of PhCO), 7.57 (d, $J=7.6 \mathrm{~Hz}, 2 \mathrm{H}, 2 o-\mathrm{H}$ of PhCO). - MS (EI, $70 \mathrm{eV}): m / z(\%)=342(11)[\mathrm{M}]^{+}, 314(10)\left[\mathrm{M}-\mathrm{C}_{2} \mathrm{H}_{4}\right]^{+}$, $139(10)\left[\mathrm{ClC}_{6} \mathrm{H}_{4} \mathrm{CO}\right]^{+}, 111(5)\left[\mathrm{C}_{6} \mathrm{H}_{4} \mathrm{Cl}\right]^{+}$.

Irradiation of trans-1-p-chlorophenyl-3-phenyl-2,3-epoxy-1propanone $(\mathbf{l h})$

PLC, petroleum ether:ethyl acetate $=15: 2$, two times; zone $1\left(R_{\mathrm{f}}=0.84\right), 68 \mathrm{mg}(48 \%$ based on consumed $\mathbf{1 h}$ and $32 \%$ based on used $\mathbf{1 h}$ ) of $\mathbf{5}$, washed with $n$-hexane; m.p.: $85-88{ }^{\circ} \mathrm{C}$; zone $2: R_{\mathrm{f}}=0.61,30 \mathrm{mg}(18 \%$ based on consumed $\mathbf{1 h}$ and $14 \%$ based on used $\mathbf{1 h}$ ) of $\mathbf{7 h}$; zone 3 $\left(R_{\mathrm{f}}=0.49\right)$ recovered $\mathbf{1 h}(43 \mathrm{mg}, 20 \%$ based on used $\mathbf{1 h})$; zone $4\left(R_{\mathrm{f}}=0.38\right), 56 \mathrm{mg}$ ( $39 \%$ based on consumed $\mathbf{1 h}$ and $26 \%$ based on used $\mathbf{1 h}$ ) of $\mathbf{4 h}$, recrystallized from $n$ hexane/ethyl acetate; m.p.: $113-116^{\circ} \mathrm{C}$.

cis-3-(p-Chlorobenzoyl)-4-phenyl-2,5-dioxaspiro[4,4]nonane (4h)

IR: $\quad v=3067,2983-2933,1695,1588,1217$, $1050 \mathrm{~cm}^{-1} .-{ }^{1} \mathrm{H} \mathrm{NMR}\left(400 \mathrm{MHz}, \mathrm{CDCl}_{3}\right): \delta=1.59-1.88$ $(\mathrm{m}, 8 \mathrm{H}$, cyclopentane $\mathrm{H}), \delta=1.60(\mathrm{~s}, 5 \mathrm{H}$, cyclopentane $\mathrm{H})$, $1.88(\mathrm{~s}, 3 \mathrm{H}$, cyclopentane $\mathrm{H}), \mathrm{AB}$ system $\left(\delta_{\mathrm{A}}=5.45, \delta_{\mathrm{B}}=\right.$ $\left.5.61,{ }^{3} J_{\mathrm{AB}}=8.0 \mathrm{~Hz}, 2 \mathrm{H}, 3-\mathrm{H}, 4-\mathrm{H}\right), 7.1(\mathrm{~s}, 4 \mathrm{H}, o-\mathrm{H}$ and $m-\mathrm{H}$ of phenyl), $7.25\left(\mathrm{~m}_{\mathrm{c}}, 2 \mathrm{H}, 2 \mathrm{~m}-\mathrm{H}\right.$ of $\left.\mathrm{PhCO}\right), 7.28$ (s, 1H, $p-\mathrm{H}$ of phenyl), $7.47(\mathrm{~d}, J=8.4 \mathrm{~Hz}, 2 \mathrm{H}, 2 \mathrm{o}-\mathrm{H}$ of $\mathrm{PhCO}) .-\mathrm{MS}$ (EI, $70 \mathrm{eV}): m / z(\%)=139(20)\left[\mathrm{ClC}_{6} \mathrm{H}_{4} \mathrm{CO}\right]^{+}, 111$ (25) $\left[\mathrm{C}_{6} \mathrm{H}_{4} \mathrm{Cl}\right]^{+}, 77(45)\left[\mathrm{C}_{6} \mathrm{H}_{5}\right]^{+}$.

\section{Acknowledgement}

We are thankful to the Center of Excellence (Chemistry) and Research Council of the University of Isfahan and the Office of Graduate Studies for their financial support.
[1] T. Miyashi, M. Kamata, T. Mukai, J. Am. Chem. Soc. 1987, 109, 2780-2788.

[2] M. Kamata, K. Komatsu, R. Akaba, Tetrahedron Lett. 2001, 42, $9203-9206$.

[3] E. Hasegawa, M. Kamata in CRC Handbook of Organic Photochemistry and Photobiology (Eds.: W. M. Horspool, F. Lenci), CRC Press, Boca Raton, 2004, chapter 53, pp. $1-17$.
[4] F. Nikpour, R. Mozafari, B. Mohammadi Moghaddam, J. Chin. Chem. Soc. 2009, 56, 404-407.

[5] F. Nikpour, S. Mohebbi, T. Paibast, M. Beigvand, Monatsh. Chem. 2008, 139, 663-667.

[6] E. Hasegawa, K. Ishiyama, H. Kashiwazaki, T. Horaguchi, T. Shimizu, Tetrahedron Lett. 1990, 28, 4045 4048. 
[7] H. R. Memarian, A. Hesami, F. Nikpour, D. Döpp, Indian J. Chem. 2001, 40B, 662-666.

[8] H. R. Memarian, F. Nikpour, Molecules 2001, 6, $63-$ 71.

[9] H. R. Memarian, F. Nikpour, J. Chin. Chem. Soc. 2002, 49, $401-406$.

[10] H. R. Memarian, F. Nikpour, Monatsh. Chem. 2002, 133, $1045-1053$

[11] H. R. Memarian, A. Saffar-Teluri, M. K. Amini, Heterocycles 2006, $68,1861-1874$.

[12] H. R. Memarian, A. Saffar-Teluri, Beil. J. Org. Chem. 2007, 3:2.

[13] H.R. Memarian, A. Saffar-Teluri, M. KhosraviBabadi, Z. Naturforsch. 2007, 62b, 1030-1034.

[14] H. R. Memarian, A. Saffar-Teluri, J. Mol. Catal. A: Chemical 2007, 274, 224-230.

[15] H. R. Memarian, F. Nikpour, H. Sabzyan, J. Iran. Chem. Soc. 2007, 4, 37-45.
[16] S. S. Lin, X. J. Kong, J. Y. Liu, C. Y. Li, Chin. Chem. Lett. 2003, 14, $907-910$.

[17] Y. Lijima, S. Obara, Y. Ohba, K. Kubo, T. Sakurai, J. Photochem. Photobiol. A 2001, 143, 23 - 29.

[18] W. Zhang, Y. P. Guo, L. Yang, Z. L. Liu, Chin. Chem. Lett. 2005, 16, 575 - 578.

[19] J. Pan, W. Zhang, J. Zhang, S. Lu, Tetrahedron Lett. 2007, 48, 2781-2785.

[20] E. Pretsch, P. Bühlmann, C. Affolter, Structure Determination of Organic Compounds, Springer Verlag, Berlin Heidelberg, 2000.

[21] C. K. Johnson, B. Doming, W. Reusch, J. Am. Chem. Soc. 1963, 85, 3894-3896.

[22] G. A. Lee, J. Org. Chem. 1973, 43, 4256-4258.

[23] S. L. Murov, Handbook of Photochemistry, Dekker, New York, 1973, pp. 79. 